Robert M. Friesen MD FRCPC, Ian R. Thomson MD FRCPC, Robert J. Hudson MD FRCPC, Morley Rosenbloom B SC (Hon), Charles L. Putnins MD FRCPC, John E. Cannon MD FRCPC.

\title{
Fentanyl oxygen anaesthesia for abdominal aortic surgery
}

\begin{abstract}
Patients who present for abdominal aortic surgery often have significant atherosclerotic disease which may involve the coronary arteries. Haemodynamic responses occurring during fentanyl ( $\left.100 \mu \mathrm{g} \cdot \mathrm{kg}^{-1}\right)$ oxygen anaesthesia for abdominal aortic surgery were studied in 16 patients. Anaesthesia was induced with fentanyl $100 \mu \mathrm{g} \cdot \mathrm{kg}^{-1}$ with no supplemental doses and metocurine-pancuronium mixture (4:1). In 13 of 16 patients hyperdynamic circulatory responses to surgical stimuli required treatment prior to aortic cross-clamping. Interventions instituted were sodium nitroprusside or nitroglycerin $(n=13)$, propranolol $(n=4)$, and diazepam $(n=4)$. The serum fentanyl concentration at time of response to surgical stimulus was $18.5 \pm 5.6 \mathrm{ng} \cdot \mathrm{ml}^{-1}$ (range $7-27 \mathrm{ng} \cdot \mathrm{ml}^{-1}$; time from induction $71 \pm 49 \mathrm{~min}, n=9)$. Eleven of the 16 patients required treatment for postoperative hypertension. Five of the 16 patients developed myocardial ischaemia, defined as ST segment depression greater than $0.1 \mathrm{mV}$, at some time during the operative procedure. Unsupplemented fentanyl anaesthesia $\left(100 \mu \mathrm{g} \cdot \mathrm{kg}^{-1}\right)$ was unable to maintain a hypodynamic circulation in patients having abdominal aortic operations.
\end{abstract}

\section{Key words}

ANAESTHETICS, INTRAVENOUS: fentanyl; SURGERY: vascular, aortic.

From the Department of Anaesthesia, University of Manitoba, Winnipeg, Manitoba.

Address correspondence to: Dr. R.M. Friesen, Department of Anaesthesia, St. Boniface General Hospital, 409 Tache Avenue, Winnipeg, Manitoba, R2H 2 A6.

Presented at the American Society of Anesthesiologists' Annual Meeting October, 1985.

Supported by a grant from the Manitoba Heart Foundation.
High-dose fentanyl-oxygen anaesthesia has been widely used for coronary artery bypass grafting because of its initially reported minimal effects on cardiovascular dynamics. Several subsequent reports have refuted these initial contentions. Patients requiring abdominal aortic surgery have significant atherosclerotic disease which may involve the coronary arteries. ${ }^{1}$ Cross-clamping and unclamping of the abdominal aorta during aortic aneurysm resection or aorto-iliac bypass grafting can be associated with severe haemodynamic disturbances, the consequences of which may include myocardial ischaemia, ${ }^{2,3}$ cardiac arrhythmias ${ }^{2}$ and evidence of left ventricular failure, ${ }^{3,4}$ High-dose fentanyl $\left(100 \mu \mathrm{g} \cdot \mathrm{kg}^{-1}\right)$, might be useful in patients having abdominal aortic operations if it provided cardiovascular stability, "stress-free" anaesthesia and facilitated postoperative emergence. ${ }^{5}$ We therefore investigated the effects of high-dose fentanyl anaesthesia in patients having abdominal aortic operations.

\section{Methods}

Following institutional approval, informed consent was obtained from 16 patients undergoing elective abdominal aortic surgery. Antianginal and antihypertensive medications were continued up to the time of surgery. Preoperative hydration was maintained by intravenous infusion established the night prior to surgery $\left(1.25-1.50 \mathrm{ml} \cdot \mathrm{kg}^{-1} \cdot \mathrm{h}^{-1}\right)$. All patients were premedicated with scopolamine, $0.006 \mathrm{mg} \cdot \mathrm{kg}^{-1}$ $\mathrm{IM}$, and morphine $0.1 \mathrm{mg} \cdot \mathrm{kg}^{-1} \mathrm{IM}$. Intravenous, radial arterial and thermodilution pulmonary arterial catheters were established using local anaesthesia, prior to induction.

Cardiovascular variables measured included heart rate (HR), mean arterial pressure (MAP), central venous pressure (CVP), cardiac output (CO) and pulmonary capillary wedge pressure (PCWP). Measurements were taken prior to induction (control), 
one minute prior to intubation, one minute after intubation, one minute after skin incision, two minutes before and after clamping and unclamping of the aorta. Additional measurements were made at the discretion of the anaesthetist. Cardiac index (CI) and systemic vascular resistance (SVR) were calculated using standard formulae. ${ }^{6}$ Data are reported as mean \pm SD. Electrocardiographic leads II and CS 5 were monitored and continuously recorded using a battery-operated Holter monitor (Del Mar Avionics). Holter recordings were retrospectively analyzed in a blinded fashion.

After the invasive monitors were established the patients were allowed to breathe 100 per cent oxygen for five minutes following which control haemodynamics were measured. Anaesthesia was induced with fentanyl, $100 \mu \mathrm{g} \cdot \mathrm{kg}^{-1}$ given over $2 \mathrm{~min}$, immediately preceded by metocurine $0.1 \mathrm{mg} \cdot \mathrm{kg}^{-1}$ and pancuronium $0.025 \mathrm{mg} \cdot \mathrm{kg}^{-1}$. Patients were randomized in a double blind fashion to receive either lidocaine $1.5 \mathrm{mg} \cdot \mathrm{kg}^{-1}$ or saline intravenously $2 \mathrm{~min}$ prior to intubation. When spontaneous ventilation became inadequate positive pressure ventilation by face mask was instituted with 100 per cent oxygen. The patients were intubated 4 min after the fentaryl infusion. Adequacy of ventilation was insured by continuous end-tidal $\mathrm{CO}_{2}$ monitoring, verified by serial arterial blood gas determinations.

During anaesthesia, a greater than 20 per cent increase in MAP from the control value was treated with intravenous infusion of sodium nitroprusside (SNP) or nitroglycerin (TNG). PCWP greater than 20 torr was treated with TNG infusion. Tachycardia (HR greater than 100 beats $\cdot \mathrm{min}^{-1}$ ) or increases in HR $>20$ per cent above control and/or associated with ST segment depression were treated with incremental doses of intravenous propranolol $(0.5-$ $2.0 \mathrm{mg}$ ). Other anaesthetic drugs given at the discretion of the anaesthetist were diazepam 2.5-10 $\mathrm{mg}$ IV and, following removal of the aortic cross-

TABLE I Preoperative medication

\begin{tabular}{ll}
\hline None & 5 \\
Beta blockers & 7 \\
Diuretics & 7 \\
Other antihypertensives* & 4 \\
Digoxin & 2 \\
Nitrates & 1 \\
\hline
\end{tabular}

*Alpha methyldopa, hydralazine, nifedipine. clamp, nitrous oxide 50 to 70 per cent. Neuromuscular blockade was maintained with additional small doses of metocurine and pancuronium (4:1 mixture). In ten patients arterial blood samples were drawn over a 24-hour period and fentanyl pharmacokinetics were determined. These data have been reported elsewhere. $^{?}$

\section{Results}

Eleven male and five female patients were studied (age $69 \pm 8$ years, weight $74 \pm 14 \mathrm{~kg}$ ). Eleven patients underwent resection of aortic aneurysms and five had aortobifemoral grafting. Ten patients had a history of hypertension and six had chronic stable angina. Regularly prescribed preoperative medications are summarized in Table $\mathbf{I}$. Control haemodynamic variables are shown in Table II. Lidocaine made no difference in the haemodynamic response to intubation (Fisher Exact Probability Test). Data were subsequently pooled.

Hyperdynamic responses (as defined by an increase $>20$ per cent in HR and/or MAP) occurred frequently. Two patients required therapy for hypertension and/or tachycardia at induction of anaesthesia, prior to intubation. Three more patients were treated for hyperdynamic responses after tracheal intubation. The majority (13/16) of patients required intervention during the surgical stimuli of laparotomy and retroperitoneal dissection. Because almost all patients received therapy to restore their haemodynamic variables to control values, these data are not reported. Eleven of 16 patients required therapy for postoperative hypertension. The incidence of hyperdynamic responses and medications administered are summarized in Table III. The serum fentanyl concentration at time of response to surgical stimulus was $18.5 \pm 5.6 \mathrm{ng} \cdot \mathrm{ml}^{-1}$ (range $7-27 \mathrm{ng} \cdot \mathrm{ml}^{-1}, \mathrm{n}=9$ ). One of ten patients in the pharmacokinetics study did not respond haemody-

TABLE II Control haemodynamics Mean \pm SD

\begin{tabular}{lc}
\hline HR & $57 \pm 7$ beats $\min ^{-1}$ \\
MAP & $13.8 \pm 1.7 \mathrm{kPa}(104 \pm 13)$ \\
PCWP & $2.2 \pm 0.7 \mathrm{kPa}(16.7 \pm 5.2)$ \\
CVP & $1.2 \pm 0.5 \mathrm{kPa}(8.9 \pm 3.5)$ \\
CI & $2.20 \pm 0.41 \mathrm{~L} \cdot \mathrm{min} \cdot \mathrm{m}^{-2}$ \\
SVR & $1952 \pm 422 \mathrm{dyne} \cdot \mathrm{sec} \cdot \mathrm{cm}^{-5}$ \\
\hline
\end{tabular}

( ) $\mathrm{mmHg}$. 
TABLE III Therapy for hyperdynamic reactions $(n=16)$

\begin{tabular}{llllll}
\hline & $\begin{array}{l}\text { Induction } \\
(2)\end{array}$ & $\begin{array}{l}\text { Intubation* } \\
(5)\end{array}$ & $\begin{array}{l}\text { Surgical } \\
\text { stimulus } \\
(13)\end{array}$ & $\begin{array}{l}\text { Aortic } \\
\text { cross-clamp } \\
(11)\end{array}$ & $\begin{array}{l}\text { First 24 hour } \\
\text { post-op } \\
(11)\end{array}$ \\
\hline SNPTNG & 2 & 5 & 13 & 11 & 11 \\
$\begin{array}{l}\text { Propranolol } \\
\text { Diazepam }\end{array}$ & 1 & 1 & 4 & 1 & 74 \\
$\begin{array}{l}\text { Morphine } \\
\text { Hydralazine }\end{array}$ & & 4 & & 9 \\
\hline
\end{tabular}

( ) Number of patients being treated at each time interval could be initiated during previous cvent and continued.

* $\mathrm{PaCO}_{2}=5.2 \pm 1.1 \mathrm{kPa}$.

tResumed as routine maintenance from pre-operative history.

SNP Sodium nitroprusside.

TNG Nitroglycerin.

namically to surgical stimuli. Of the other nine, only one patient had a serum fentanyl level greater than $25 \mathrm{ng} \cdot \mathrm{ml}^{-1}$ when a hyperdynamic response occurred. The time from induction of anaesthesia to development of hypertension or tachycardia was 71 \pm 49 minutes.

Three patients had episodes of ST depression: at induction, immediately after tracheal intubation and after cross-clamping of the aorta. These episodes occurred in different patients and resolved with appropriate therapy. Two further episodes of ST depression were detected only after reviewing the Holter monitor recordings. Both episodes occurred at tracheal intubation in patients subsequently treated for hyperdynamic responses (Table IV).

In 14 of 16 patients ventilatory support was discontinued the day following surgery. The remaining two patients developed postoperative respiratory insufficiency and required ventilatory support for 45 and 96 hours respectively. There were no episodes of intraoperative awareness.

\section{Discussion}

The present study indicates that anaesthesia with a single bolus of fentanyl, $100 \mu \mathrm{g} \cdot \mathrm{kg}^{-1}$, does not provide stable haemodynamics in the majority of patients undergoing abdominal aortic surgery. Highdose fentanyl also does not uniformly abolish autonomic reflexes during coronary artery surgery. ${ }^{8,9}$ The incidence of hyperdynamic responses in our patients was higher than in patients having coronary artery surgery.

Clinically significant hyperdynamic responses (hypertension and tachyardia) to induction of anaes- thesia with fentanyl and a variety of muscle relaxants have recently been reported. ${ }^{10,11}$ Two such episodes occurred in this study (Table III). Hypercarbia and muscle rigidity have been postulated as possible aetiologies. However, we monitored endtidal $\mathrm{PCO}_{2}$ continuously and prevented rigidity by administering muscle relaxant prior to injection of fentanyl. Endogenous catecholamine release caused by fentanyl might explain these hyperdynamic responses to induction of anaesthesia.

The high frequency of haemodynamic responses in our patients suggests that abdominal aortic surgery may be a greater surgical stimulus than coronary artery surgery. While nine of our ten patients responded to surgical stimuli in the presence of a serum fentanyl concentration of $18.5 \mathrm{ng} \cdot \mathrm{ml}^{-1}$ only 21 per cent of patients in another study ${ }^{9}$ responded to sternotomy when the mean serum fentanyl concentration was $18 \mathrm{ng} \cdot \mathrm{ml}^{-1}$. Our high incidence of responses indicates that this was not a "stressfree" anaesthetic.

It is possible that fentanyl in doses exceeding 100 $\mu \mathrm{g} \cdot \mathrm{kg}^{-1}$ given by continuous intravenous infusion would provide more stable anaesthesia. However, because the half-time of elimination for fentanyl

TABLE IV ECG ST-segment depression

\begin{tabular}{lll}
\hline Event & Detected intra-op & Holter analysis \\
\hline Induction & 1 & 1 \\
Post ETT & 1 & 3 \\
Aortic cross-clamp & 1 & 1 \\
Total & 3 & 5 \\
\hline
\end{tabular}


averaged 8.7 hours in ten of these patients, ${ }^{7}$ prolonged postoperative respiratory depression would be expected. Fentanyl-induced respiratory depression is more frequent in patients with pre-existing pulmonary dysfunction. ${ }^{12} \mathrm{~A}$ previous study of coronary artery bypass graft patients ${ }^{y}$ concluded that the possibility of increased morbidity, including prolonged postoperative respiratory depression, militated against the use of larger doses of fentanyl to determine whether there is a plasma fentanyl concentration that will consistently abolish the hypertensive response to surgical stimuli.

The incidence ( $>39$ per cent) of intraoperative ST segment depression probably reflects greater accuracy of the Holter monitoring technique. The incidence of myocardial ischaemia detected intraoperatively (3/16) is similar to that reported by others ${ }^{3}$ utilizing a variety of anaesthetic techniques for abdominal aortic surgery.

In summary, 13 of 16 patients required vasodilators, beta adrenergic blocking drugs or additional anaesthetic drugs to achieve stable intraoperative haemodynamics for abdominal aortic operations during high-dose fentanyl anaesthesia. Unsupplemented fentanyl anaesthesia was unable to maintain a hypodynamic circulation in contrast to previously described techniques.

\section{References}

1 Tomatis LA, Fierens EE, Verbrugge GP. Evaluation of surgical risk in peripheral vascular disease by coronary arteriography: a series of 100 cases. Surgery 1972; 71: 429-35.

2 Attia RR, Murphy JD, Snider $M$ et al. Myocardial ischemia due to infra-renal aortic cross clamping during aortic surgery in patients with severe coronary artery disease. Circulation 1976; 53: 961-5.

3 Carroll RM, Laravuso RB, Schauble JB. Left ventricular function during aortic surgery. Arch Surg 1976; 111: 740-3.

4 Silverstein $P R$, Caldera DL, Cullen DJ, Davison JK, Darling $R C$, Emerson $C W$. Avoiding the hemodynamic consequences of aortic cross-clamping and unclamping. Anesthesiology 1979; 50: 462-6.

5 Bovill JG, Sebel PS, Stanley TH. Opioid analgesics in anesthesia with special reference to their use in cardiovascular anesthesia. Anesthesiology 1984; 61: 731-55.

6 Stahl WR. Scaling of respiratory variables in mammals. J Appl Physiol 1967; 22: 453-60.
7 Hudson RJ, Thomson IR, Cannon JE, Friesen RM, Meatherall $R C$. Pharmacokinetics of fentanyl in patients undergoing abdominal aortic surgery. Anesthesiology 1986; 64: 334-8.

8 Moffit EA, Barker RA, Sullivan JA, Cousins CL. Myo. cardial metabolism and haemodynamic responses during high-dose fentanyl anaesthesia for coronary patients. Can Anaesth Soc J 1984; 31: 611-8.

9 Wynands JE, Wong P. Townsend GE, Sprigge JS, Whalley $D G$. Narcotic requirements for intravenous anesthesia. Anesth Analg 1984; 63: 101-5.

10 Thomson IR, Putnins $C L$. Adverse effects of pancuronium during high-dose fentanyl anesthesia for coronary artery bypass grafting. Anesthesiology 1985; 62: 708-13.

11 Thomson IR, Putnins $C L$, Friesen RM. Hyperdynamic cardiovascular responses to anesthetic induction with high-dose fentanyl. Anesth Analg 1986; 65: 91-5.

12 Holley FO. Prolonged respiratory depression in cardiac surgery patients: the contribution of fentanyl. Anesthesiology 1984; 61: A80.

\section{Résumé}

Les patients se présentant pour chirurgie aortique abdominale présentent souvent une maladie athérosclérotique pouvant atteindre les coronaires. Les réponses hérnodynamiques survenant lors de la chirurgie sur l'aorte abdominale et une anesthésie au fentanyl $\left(100 \mu \mathrm{g} \cdot \mathrm{kg}^{-1}\right)-$ $\mathrm{O}_{2}$ ont été étudiées chez 16 patients. L'anesthésie était induite avec du fentanyl $100 \mu \mathrm{g} \cdot \mathrm{kg}^{-1}$ sans dose supplémentaire de mélange et métocurine/pancuronium (4:1). Pour 13 des 16 patients les réponses hyperdynamiques au stimulus chirurgical ont requis un traitement avant le clampage aortique. Les interventions incluent la nitroprussiate de soude ou nitroglycérine $(n=13)$, propranolol $(n=4)$, diazepam $(n=4)$. La concentration sérique de fentanyl au temps de réaction au stimulus chirurgical était de $18.5 \pm 5.6 \mathrm{ng} \cdot \mathrm{ml}^{-1}$ (écart: $7-27 \mathrm{ng} \cdot \mathrm{ml}^{-1}$ ), le temps à partir de l'induction $71 \pm 49 \mathrm{~min}$. $(n=9)$. Onze des 16 patients ont requis un traitement pour l'hypertension post-opératoire. Cing des 16 patients ont développé une ischémie myocardique définie comme étant une dépression du segment ST supérieur à $0 . \operatorname{ImV}$, lors de la procédure chirurgicale. L'anesthésie au fentanyl, celle $\left(100 \mu \mathrm{g} \cdot \mathrm{kg}^{-1}\right)$ était incapable de maintenir un état hypodynamique chez les patients devant subir une chirurgie sur l' aorte abdominale. 